\title{
EMPOWERMENT OF COMMUNITY ECONOMY THROUGH ZAKAT FUNDS \\ (Analysis of Zakat Fund Management Study of The National Amil Zakat Agency (BAZNAS) in Papua Province)
}

\author{
Husnul Yaqin \\ IAIN Fattahul Muluk Papua \\ husnulyaqin69@yahoo.co.id
}

\begin{abstract}
Zakat is one of the pillars of Islam that is required of all Muslims whose wealth has reached Nisab. The collection of BAZNAS zakat funds in Papua province through several stages, namely through socialization to several institutions both public and private and initially originated from UPZ funds in the Jayapura region. Based on the recapitulation of zakat funds in Papua province through BAZNAS in 2018 amounting to Rp. $963,858,000$. The distribution of zakat funds carried out by BAZNAS in Papua province is not only a consumptive way but also in a productive way, this is an effective way for community economic empowerment such as assistance distributed to 5 Papuan Muslims, assistance through BKMT, zakat fostered villages (Ambon and Dobonsolo villages) and empowerment of spinach farmers in Mappi district. In addition to the economic empowerment of the people through zakat there is also the provision of scholarship assistance ranging from elementary, junior high, high school and university, in 2018 a number of 23 people have received scholarship assistance through zakat funds. According to the analysis of researchers that the recapitulation of zakat funds shows that between the receipt of Rp. $963,858,000$ and expenditure or distribution of $\mathrm{Rp}$. 438,811,500 were unbalanced, so the discovery by the audit team occurred because the distribution was less than $70 \%$.
\end{abstract}

\section{INTRODUCTION}

The problem of poverty in Indonesia is very alarming, it has been more than 74 years of Indonesia's independence and more than 18 years of reform, but the problem of poverty has become an urgent problem in Indonesia's development. In fact, poverty alleviation programs are always listed in development programs from time to time, with poverty alleviation funds that continue to increase. The problem of poverty is discussed without ending in real action, therefore it attracts many people to be resolved in an appropriate and smart way. Everyone seems eager to talk about how poor this country is, a country that is said to be beautiful, its fertile nature produces lucrative plants, but it turns out that all that remains is just a story of the past. Poverty remains an inseparable part of this beautiful nation. What is even more pathetic is that the acute disease of poverty turns out to have lodged in the body of the majority of Muslims, it attacks the bodies of the people who actually have the values of the struggle for success in the afterlife, but then must experience a "catastrophe" of extreme poverty.

In the book World in Figure 2003, published by The Economist, described Indonesia as an extraordinary country, the 15th largest country in the world, was known as the world's number 3 exporter of chocolate, the second largest producer of palm oil, and a variety of results other plantations, from mining revenues, it turns out that 
Indonesia produces the 8th gold in the world, this country produces a lot of bauxite, fuel oil, coal, marble, nickel and other mineral contents. ${ }^{1}$

Islam has a high concern for releasing the poor and disadvantaged from poverty and background. Islam is very consistent in alleviating poverty, Islam really has a very mature concept to build social order based on mutual help and mutual cooperation. The rich must set aside a small portion of their wealth for the poor and other groups. The gift can be in the form of zakat, infaq and alms. The issuance of zakat is an obligation for every Muslim who is able and has fulfilled the requirements with the provisions of Islamic sharia. Even one of the five pillars of Islam. It cannot be denied that zakat is very potential as an effective means of empowering the economic community. ${ }^{2}$

This huge potential of zakat is inseparable from the economic development of the Ummah especially in Papua because each year the number of muzakki increases and the amount of zakat money is also based on annual reporting in the month of Ramadan by the Zakat Collection Unit in every mosque in Papua. The economic development of the Ummah has been able to significantly increase the income of Papuans. Increasing the income and standard of living of most Muslim communities, especially in Papua, has certainly made the potential for zakat payments even greater.

Papua Provincial Baznas whose duty is to manage zakat, infaq, and alms, seeing from most of the Papuan people who are Muslim then zakat is actually an economic sector that has the potential to be developed and can reduce poverty. However, efforts to explore the potential and optimization of the role of zakat in Papua have not been fully exploited to the maximum because the role of zakat has not been carried out effectively and efficiently. Many factors that cause the benefits of zakat have not been felt maximally, including the weak religious motivation and Islamic awareness in the majority of the community so that the low awareness of the community in fulfilling the obligation to pay zakat, lack of supervision from zakat management institutions in the distribution of zakat so that it may be the parties involved zakat should not get their rights, zakat is given to eight groups not only given to the poor and poor, zakat given to mustahik is mostly used for instant consumption so there is no economic activity that can develop the wealth of the mustahik, and zakat should given by muzakki to mustahik not only in the form of money but also in the form of venture capital and educational scholarships.

The potential of zakat collected by each UPZ which is then announced at each Eid prayer from each BKMM is on average above 2 billion. Moreover, alms in all the provinces of Papua it is possible for him to top 20 billion. This then the role of zakat is expected to be a means to alleviate poverty and get great attention, the completion of poverty reduction must be done immediately and zakat is expected to have a contribution to the poor, especially those who need attention from all parties. Such efforts are made in developing the potential of zakat through efforts to empower poor alms to empower Papuan Muslim families and the training and skills of jama'ah (Islamic communities in the paua region) so that the poor will have the form of experience that can be used to change their lives to be more both as well as scholarships given to students and Islamic students in Papua.

The potential and role of zakat in Papua province illustrates how the influence of the potential and the role of zakat in the community which includes how the influence

\footnotetext{
${ }^{1}$ Sumber://demustaine.blogdetik.com/2008/08/27/zakat-dan-kemiskinan. Akses di Jayapura, 25 Februari 2018

${ }^{2}$ Jurnal Hikmatuna, Akses di Jayapura, 25 Februari 2018.
} 
of zakat on poverty alleviation, zakat potential, the influence of venture capital assistance and the influence of zakat utilization assistance in society. For this reason, research is needed that looks at the economic empowerment of the people through zakat funds (An Analysis Study of the Management of BAZNAS in Papua Province).

\section{THE MEANING OF ZAKAT IN THE QUR'AN}

In the Koran raises the issue of zakat in four terms or terms, namely: zakat, infaq, sadaqah and haq. Among the verses of the Qur'an which mention the four terms or terms are as follows:

Zakat terms contained in the word of God Almighty QS. al Haj: 78:
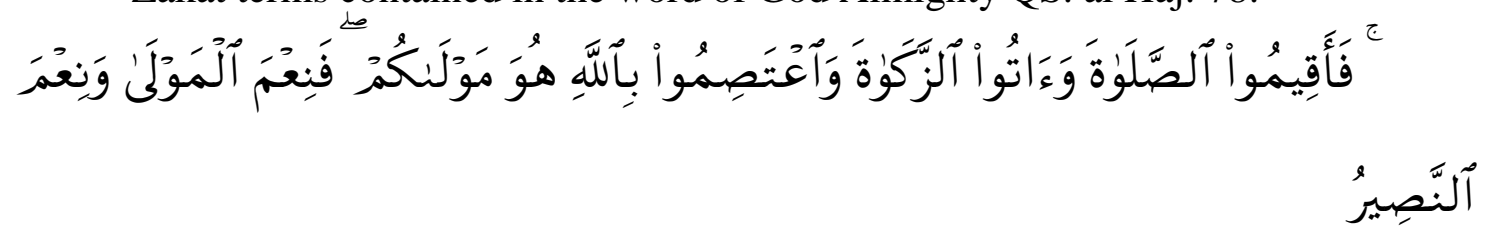

Translation:

"Then establish prayer, pay alms and hold on to the cords of God. He is your Protector, So He is the Best Protector and the best helper."

Term infaq which refers to the meaning of zakat is contained in the word of God Almighty QS al Baqarah / 2: 267;

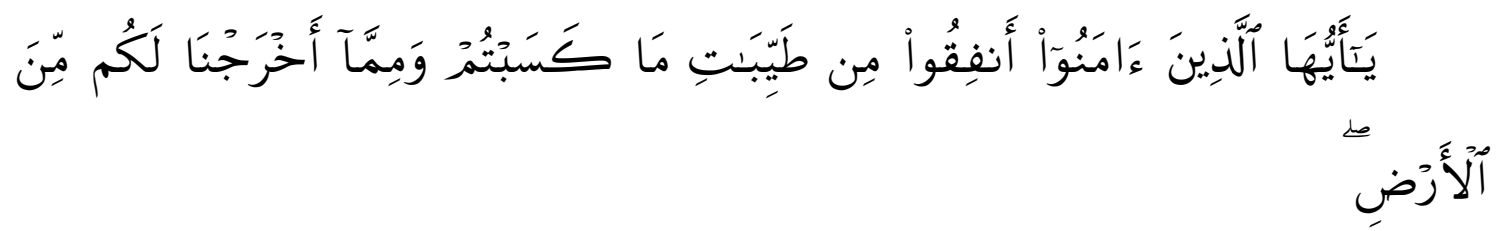

Translation:

"O you who believe, spend (in the way of Allah) some of the results of your good efforts and some of what we spend from the earth for you."

The term shadaqah which refers to the meaning of zakat is contained in the word of God Almighty QS. al-Taubah: 103:



Translation:

"Take alms from some of their assets, with that you cleanse and purify them and pray for them."

The words infaq and sadaqah in the two verses above each refer to the meaning of zakat. This can be traced through the anfiq lafad and lafad khud which use the sighat amr lafad (word for command) which contains the meaning of obligation If what is meant by infaq and sadaqah in these two verses is infaq or ordinary sadaqah, then surely

\footnotetext{
${ }^{3}$ Maksudnya zakat itu membersihkan mereka dari kekikiran dan cinta yang berlebih-lebihan kepada harta benda, sedangkan maksudnya zakat itu menyuburkan sifat-sifat kebaikan dalam hati mereka dan memperkembangkan harta benda mereka.
} 
Allah does not need to use shighat amr, because infaq and sadaqah are ordinarily sunnah. Therefore, it is appropriate if infaq and shadaqah are interpreted as zakat.

Term haq which refers to the meaning of zakat is contained in the word of Allah Almighty: 141:



Translation:

"And it is He who makes gardens that uphold and do not uphold, palm trees, plants of various kinds of fruit, olives and pomegranates that are similar (shape and color) and not the same (taste). eat from its fruits (which are various) when He bears fruit, and exercise its rights on the day of reaping the rewards (by giving it to the poor); and don't overdo it. Verily, Allah does not like exaggerated people."

Basically the four terms above have their respective meanings and have differences and similarities between one and the other. However, contextually these four terms can be understood as pointing to the meaning of zakat.

\section{THE PATTERN OF COLLECTING BAZNAS IN PAPUA PROVINCE}

Payment of zakat is one of the pillars of Islam that is required to all Muslims whose total wealth has reached Nisab, consisting of zakat fitrah and zakat maal. Collecting and channeling zakat funds with the conventional system should be ended and changed, namely by: 1) reconstruction of the concept of zakat, and 2) the model of zakat distribution must be changed from a system of equal distribution to a priority scale system, because the potential for zakat in Indonesia reaches 4, 9 billion US dollars or Rp 44.1 trillion, so that the real sector will be able to be mobilized if this kind of fund is well managed so that the community is able to be independent and poverty is successfully overcome. ${ }^{4}$

The pattern of collecting zakat funds in BAZNAS in Papua province through several stages, namely by socializing to several institutions both public and private. This is as said by the chairman of the Papua province BAZNAS. Besides that, the collection of BAZNAS in Papua Province was originally sourced from UPZ funds in the Jayapura region. Based on the recapitulation of zakat funds in Papua province through BAZNAS in 2018, namely:

${ }^{4}$ http://yannacirebon.blogspot.com/2013/12/strategi-pengentasan-kemiskinan-di.html, Di akses di Jayapura, 22 September 2018. 


\begin{tabular}{|c|c|c|c|c|c|}
\hline No. & Rincian & Zakat & Infaq & Jumlah & Keterangan \\
\hline 1. & 2. & 3. & 4. & 5. & 6. \\
\hline 1. & Receipt & $\begin{array}{l}\text { Rp. } \\
896.756 .500\end{array}$ & $\begin{array}{l}\text { Rp. } \\
67.101 .500\end{array}$ & $\begin{array}{l}\text { Rp. } \\
963.858 .000\end{array}$ & $\begin{array}{l}\text { Unpaid } \\
\text { zakat fund } \\
\text { Rp. } \\
\text { 525.046.500 }\end{array}$ \\
\hline 2. & Distribution & $\begin{array}{l}\text { Rp. } \\
397.568 .000\end{array}$ & $\begin{array}{l}\text { Rp. } \\
41.243 .500\end{array}$ & $\begin{array}{l}\text { Rp. } \\
438.811 .500\end{array}$ & \\
\hline
\end{tabular}

Data obtained from treasurer BAZNAS Papua province ${ }^{5}$

From the data above shows that this is a small portion of ZIS that has been deposited through the Papua Province BAZNAS in 2018 amounting to Rp. 963,858,000, - if all UPZs in Papua province have submitted ZIS through the BAZNAS in Papua province, it will be far more effective in its management.

Based on the above data, if the pattern of collecting zakat funds is done by several motives or methods, then the results of zakat, infaq sadaqah (ZIS) will be much more. From this the researchers will discuss the methods or patterns of collecting ZIS funds that are effective and will get the maximum zakat funds, namely through socialization.

Zakat socialization means the process or effort to disseminate the teachings of zakat to the public so that it can be easily accepted, understood, and practiced by the public. Basically every Muslim believes that zakat is an indicator of one's Islam, therefore a person who denies zakat cannot be said to be a Muslim. this belief is usually difficult to realize due to various factors, both internal and external factors. lack of information regarding the procedures for implementing zakat is one of the factors that inhibits the realization of the teachings of zakat. likewise information that is not systematic and difficult to understand will cause someone to anticipate the teachings of zakat. $^{6}$

Therefore, the socialization of the government and scholars related to zakat management organizations in people's lives is absolutely necessary. Because socialization in the context of the teachings of zakat is important in order to uphold the law and the function of zakat as a permanent institution that cannot be separated from prayer for Muslims. Related to methods that can be used in the dissemination of zakat including lectures, training, workshops, door to door, and participatory.

\section{DISTRIBUTION PATTERN OF ZAKAT BAZNAS IN PAPUA PROVINCE}

Zakat funds traditionally distributed directly by muzaki to mustahik tend to be consumptive so that there will be no significant impact on efforts to reduce poverty, therefore a trustworthy institution is needed in channeling these funds so that the

\footnotetext{
${ }^{5}$ Data di peroleh dari Bendahara BAZNAS Provinsi Papua: Ibu Nalah tanggal 19 September 2018.

${ }^{6}$ Muhammad Hasan, Manajemen Zakat: Model Pengelolaan Zakat Yang Efektif, Yogyakarta: Idea Press Yogyakarta, 2011, hal. 57 dan 59.
} 
problem of poverty in this country can be overcome. In addition, if there is no synergy between UPZ and BAZNAS, it is feared that the zakat funds raised by UPZ cannot be channeled to the poor who really need financial assistance for business activities.

The distribution of zakat funds carried out by BAZNAS in Papua province is not only a consumptive way but also in a productive way, this is an effective way for community economic empowerment such as assistance distributed to 5 Papuan Muslims, assistance through BKMT, zakat fostered villages (Ambon and Dobonsolo villages) and empowerment of spinach farmers in Mappi district. ${ }^{7}$

In addition to the economic empowerment of the people through zakat there is also the provision of scholarship assistance ranging from elementary, junior high, high school and university, in 2018 a number of 23 people have received scholarship assistance through zakat funds. ${ }^{8}$

The distribution of zakat funds in each year is not allowed less than $70 \%$, if it does not run out up to $70 \%$ then it is considered a finding or holding zakat funds. So that the BAZNAS Papua province in 2016 when there was an audit from the Center, the value is very low 30 even though the minimum value is $60 .^{9}$

ZIS BAZNAS Recapitulation of Papua Province

\begin{tabular}{|c|c|c|c|c|c|}
\hline No & Details & Zakat & Infaq & Total & Information \\
\hline 1. & Receipt & $\begin{array}{l}\text { Rp. } \\
896.756 .500\end{array}$ & $\begin{array}{l}\text { Rp. } \\
67.101 .500\end{array}$ & $\begin{array}{l}\text { Rp. } \\
963.858 .000\end{array}$ & $\begin{array}{l}\text { Zakat funds } \\
\text { that are not } \\
\text { channeled } \\
\text { Rp. } \\
525.046 .500\end{array}$ \\
\hline 2. & Distribution & $\begin{array}{l}\text { Rp. } \\
397.568 .000\end{array}$ & $\begin{array}{l}\text { Rp. } \\
41.243 .500\end{array}$ & $\begin{array}{l}\text { Rp. } \\
438.811 .500\end{array}$ & \\
\hline
\end{tabular}

Researchers argue that the recapitulation of the zakat funds above shows that between the receipt of Rp. 963,858,000 and expenditure or distribution of Rp. $438,811,500$ were unbalanced, so the discovery by the audit team occurred because the distribution was less than $70 \%$.

The distribution of zakat can be done in various patterns, depending on the managerial policy of the Zakat Agency or Institution concerned. Sometimes it is channeled directly to the mustahik with a consumptive pattern and sometimes it is realized in a productive position or by providing capital or zakat can be developed with an investment pattern.

\footnotetext{
${ }^{7}$ Wawancara dengan ketua BAZNAS Provinsi Papua Ir.H.Edi Mirza Nazari, pada tanggal 04 September 2018.

${ }^{8}$ Ibid.

${ }^{9}$ Wawancara dengan wakil ketua BAZNAS Provinsi Papua bapak H.Syafi'i, pada tanggal 04 September 2018.
} 
Zakat which has been collected by BAZNAS from the muzakkih must be distributed or distributed to those entitled to receive it (mustahiq) as determined by the shari'ah as stated in the word of Allah QS. at Taubah: 60:

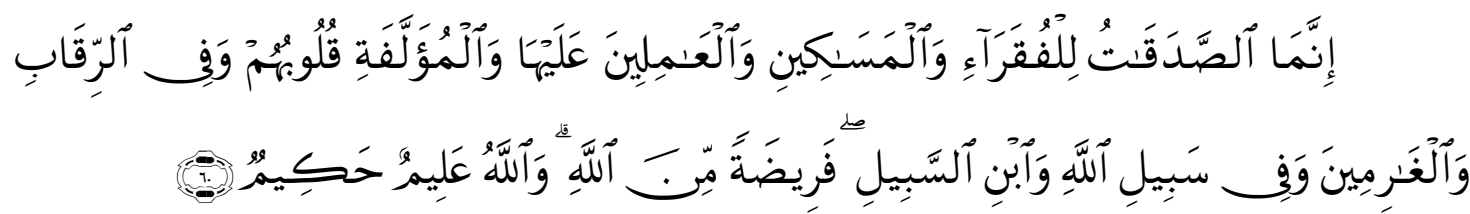

Translation:

"Surely the zakat is only for the needy, the poor, the administrators of zakat, the Mu'allaf who are persuaded by their hearts, to (liberate) slaves, those who are in debt, to the way of Allah and to those who are yuang is on its way, as a decree that is required of Allah, and Allah knows the Wise."

\section{MANAGEMENT OF BAZNAS ZAKAT FUNDS IN PAPUA PROVINCE IN POVERTY ALLEVIATION MEASURES}

Zakat is the third pillar of Islam, in this third pillar is different from the other pillars in terms of relations with fellow human beings (hablun min al-nas) because in this worship involves the distribution of wealth from rich people (muzakki) to those who are entitled to receive it.

In the Islamic view, the government is responsible for the welfare of its people because the government as "the caliph of Allah" bears the mandate of Allah and as the "caliph khal'ifillah" bears the mandate of all his people.

Zakat management agency or institution is the ruler or government as an agency that is authorized to handle zakat. This is in accordance with the understanding of verse 103 of Surah al-Tubah, the hadiths of the Prophet both in the form of words and in the form of deeds and wisdom of al-Khulafaur Rashidin. ${ }^{10}$

According to al-Shaukani zakat must be submitted to the government through the state apparatus called by Allah as "al-amilin alayhi". al-amilin is included as a group of people entitled to receive zakat in the third order, thus showing that zakat is not an obligation assigned to individuals but it is a state duty. The government must take care of, supervise and appoint amil who manage zakat both as collectors, depositors, bookkeepers and distributors.

The management of zakat in the Papua province as conveyed by the chairman of the BAZNAS Papua province that, BAZNAS is a non-structural government institution that is independently accountable to the President. BAZNAS was formed by Presidential Decree (Keppres) RI No. 8 of 2001 dated 17 January 2001. The Board of Papua Province Baznas was confirmed based on the Decree of the Governor of Papua Province, number: 188.4 / 405/2015, on 18 November 2015 and was inaugurated on 18 January 2016.

The provincial BAZNAS carries out two functions, namely the function of the provincial zakat coordinator, and the limited function of provincial zakat operators.

\footnotetext{
${ }^{10}$ Sjechul Hadi Permono, Formula Zakat Menuju Kesejahteraan Sosial, (Surabaya: Aulia, 2005),h.132.
} 
1. The function of provincial zakat coordinator:

a. The coordinating role of the BAZNAS district or city and the provincial LAZ related to policies and guidelines for the management of zakat that has been established by BAZNAS.

b. Responsible for reporting zakat at the provincial level which includes reports from provincial BAZNAS, district / city BAZNAS, and provincial LAZ.

c. Providing recommendations for the opening of National LAZ representatives in the province.

2. The functions of zakat operators at the provincial level are limited:

a. Conduct collections in the scope of offices of vertical agencies, offices of regional work units or provincial regional institutions, provincial-owned enterprises, private-scale companies, universities, and grand mosques.

b. In distribution, the provincial BAZNAS cooperates with the district/city BAZNAS to be able to organize the distribution and utilization of zakat to mustahik. $^{11}$

In Indonesia, there are many Zakat Management Institutions (IPZ), based on DGT Regulation No. PER-15 / PJ / 2012 there are 19 IPZs determined as zakat managers consisting of $1 \mathrm{BAZ}, 15 \mathrm{LAZ}$, and 3 LAZIS, but in the management of zakat funds there is a lack of transparency, this can be proven by the lack of information provided about the amount of funds zakat collected by LAZ and LAZIS, there are only a few IPZ whose financial reports are published on its website so that LAZ is considered lacking transparency and accountability, therefore LAZ's function as baitul maal must be reviewed with LAZ's independent supervisory authority so that transparency and accountability LAZ is guaranteed and public concerns are not proven about the zakat funds raised by LAZ not channeled as a whole for poverty reduction.

The strategy adopted by the government in Indonesia is a growth with equity strategy, not a growth and equity strategy. In the growth with equity strategy the priority is economic growth rather than equality, for example the condition of economic growth is improved in terms of equity or the form of equity can be seen from the level of poverty and unemployment that is the target of reducing poverty and unemployment in the Draft State Budget is targeted to be a percentage and economic growth target of a few percent however the poverty reduction and unemployment target is relatively small, which is the impact of the implementation of the form of a growth strategy with equity, because it is not focused on the balance of the growth and equity strategy, therefore a fair policy must be made so that economic growth improves along with a decrease in poverty and significant unemployment.

Giving zakat should be productive so that the necessities of life mustahik can be fulfilled and can live independently as the Prophet said: Meaning: "Prophet Muhammad said: It is not lawful to beg unless one of the three: First, people who bear a heavy burden, for him halal ask, Secondly, people who are beaten by disaster, then for him to also ask halal. Third, people who are plagued by poverty, so for him also lawful to ask

\footnotetext{
${ }^{11}$ Wawancara dengan ketua BAZNAS Provinsi Papua Ir.H.Edi Mirza Nazari, pada tanggal 04 September 2018.
} 


\section{Empowerment of Community Economy Through Zakat Funds (Analysis of Zakat Fund Management Study of The National Amil Zakat Agency (BAZNAS) in Papua Province)}

to return upright and live a normal life. "As for the above mentioned forbidden for him to eat from the results of begging". ${ }^{12}$

The government must be selective in distributing zakat to make it right on target. Someone who has a job with an adequate income, then the work must not be abandoned because of obtaining Zakat, as the Prophet said: "Alms are not lawful for rich people, able-bodied people and strong".

Human Resources (HR) managers of zakat funds must be trustworthy and knowledgeable, as explained in the Qur'an about the two characteristics of successful state wealth management, can be learned from the words of the Prophet Joseph to the ruler of Egypt as the word of Allah swt in the QS. Yusuf: 55:



\section{Translation:}

"Said Yusuf: "Make me the treasurer of the country (Egypt); I am indeed a man who is good at guarding, more knowledgeable."

From this verse it is known that the first trait that must be possessed by BAZNAS HR is to be good at guarding, meaning that it is very strong in safeguarding the country's wealth, so that gifts in any form originating from Baitul Maal must be rejected, and salary must be calculated carefully. The second nature of people who deal with matters of state assets is knowledgeable, that is, they must have expertise.

Programs created by BAZNAS for the distribution of zakat funds should be productive on condition that the primary needs of the poor are met. So the allocation of zakat funds for the productive sector comes from another ashnaf mentioned in the Qur'an. The management of zakat funds should be an institution originating from a country that functions as baitul maal and is non-profit so that the amil funds and operational funds of zakat management institutions can be minimized, therefore the function of BAZNAS must be optimized and there must be synergies in the use of technology for collecting zakat funds so that the obligations zakat, the muzaki can be paid off easily.

\section{CONCLUSION}

After researchers describe various descriptions of the results of this study, to facilitate understanding for readers of this study, it can be concluded:

1. The pattern of collecting zakat funds in the BAZNAS Papua province through several stages, namely by socializing to several agencies both public and private. This is as said by the chairman of the Papua province BAZNAS. Besides that, the collection of BAZNAS in Papua Province was originally sourced from UPZ funds in the Jayapura region. ZIS that has been deposited through BAZNAS in Papua province in 2018 amounted to Rp. 963,858,000, - if all UPZs in Papua province have submitted ZIS through the BAZNAS in Papua province, it will be far more effective in its management.

\footnotetext{
${ }^{12}$ Qardawi, Yusuf. 2006. "Hukum Zakat : Studi komparatif Mengenai Status dan Filsafat Zakat Berdasarkan Qur'an dan hadis" diterjemahkan oleh : Harun, Salman. Hafidhuddin, Didin \& Hasanuddin, (PT. Pustaka Litera Antar Nusa, Jakarta, 2006), h: 529.
} 
2. The distribution of zakat funds conducted by the BAZNAS in Papua province in 2018 is Rp. 438,811,500. The distribution of BAZNAS zakat funds in Papua Province is not only consumptive but also productive, it is an effective way for community economic empowerment such as assistance distributed to 5 Papuan Muslims, assistance through BKMT, zakat fostered villages (Ambon village and Dobonsolo) and empowerment of spinach farmers in Mappi district.

3. BAZNAS Papua province is a non-structural government agency that is independently responsible to the President. BAZNAS was formed by Presidential Decree (Keppres) RI No. 8 of 2001 dated 17 January 2001. The Board of Papua Provincial Baznas was confirmed based on the Decree of the Governor of Papua Province, number: 188.4 / 405 / year 2015, 18 November 2015 and was inaugurated on 18 January 2016. BAZNAS Provincial functions two functions, namely Function provincial zakat coordinator, and provinciallevel zakat operator functions. The function of the provincial zakat coordinator: a). The coordinating role of the BAZNAS district or city and the provincial LAZ related to policies and guidelines for the management of zakat that has been established by BAZNAS. b). Responsible for reporting zakat at the provincial level which includes reports from provincial BAZNAS, district / city BAZNAS, and provincial LAZ. c). Providing recommendations for the opening of National LAZ representatives in the province. The functions of zakat operators at the provincial level are limited: a). Conduct collections in the scope of offices of vertical agencies, offices of regional work units or provincial regional institutions, provincial-owned enterprises, private-scale companies, universities, and grand mosques. b). In distribution, the provincial BAZNAS collaborates with the district or city BAZNAS to be able to organize the distribution and utilization of zakat to mustahik.

\section{REFERENCES}

Burhan Bugin, Analisis Data Penelitian Kualitatif, Cet.II; Jakarta: PT RajaGrafindo Persada, 2003.

Departemen Agama RI, Al Quran dan Terjemahnya, PT. Sygma Ekamedia Arkanleema Bandung: 2009.

, Membangun Peradaban Zakat, (Direktorat Jenderal Bimbingan Masyarakat Islam Direktorat Pemberdayaan Zakat Tahun 2009.

Direktorat pemberdayaan Zakat Dirjen Bimasy Islam Departemen agama RI, Fiqh Zakat, tp, 2009.

Djibril dan Muhammad dan Teguh Firmansyah, Sistem Ekonomi Islam Zakat dan Wakaf, Jakarta: UI Press. 2010.

Fanani Umar, Problematika Kemiskinan, apa Konsep Islam, Terj., Surabaya: Bina ilmu, tt.

Furqon Ahmad, Manajemen Zakat, Semarang: CV. Karya Abadi Jaya, 2015. 
H. Syarwani, Ala at-Tuhfah, tt. Juz 7, tt.

Haffifuddin Didin, Zakat dan Infaq: Salah Satu Solusi Mengatasi Problema Sosial di Indonesia, Jakarta: Kencana. 2001.

Hafidhuddin Didin, Zakat dalam Perekonomian Moderen, Jakarta. Gema Insani Press, 2006.

Hasan Muhammad, Manajemen Zakat: Model Pengelolaan Zakat Yang Efektif, Yogyakarta: Idea Press Yogyakarta, 2011.

Mediacenter.riau.go.id, Akses di Jayapura, tanggal 13 September 2018.

Mursyidi, Akuntansi Zakat Kontemporer, Bandung: PT. Remaja Rosdakarya Offset, 2003.

Nashif Manshur Ali, Mahkota Pokok-pokok Hadist Rasulullah SAW, Bandung: Sinar Baru Algensindo, 2002.

Nata H. Abuddin, Metodologi Studi Islam, Cet. XVII; Jakarta: RajaGrafindo Persada, 2010.

Nawawi Ismail, Zakat dalam Perspektif Fiqh, Sosial dan Ekonomi, t.tp, th.

Permono Sjechul Hadi, Formula Zakat Menuju Kesejahteraan Sosial, Surabaya: Aulia, 2005.

Qardawi Yusuf, "Hukum Zakat : Studi komparatif Mengenai Status dan Filsafat Zakat Berdasarkan Qur'an dan hadis" diterjemahkan oleh : Harun, Salman. Hafidhuddin, Didin \& Hasanuddin, PT. Pustaka Litera Antar Nusa, Jakarta, 2006. , Hukum Zakat, Litera Antar Nusa dan Mizan, Jakarta-Bandung, 1996. , Zakat Profesi, Wacana Pemikiran dalam Fiqh Kontemporer. Jakarta: Salemba Diniyah, 1999.

Rahardjo, Dawam, Hukum Zakat, Terjemahan Salman Harun, Didin Hafidhuddin dan Hasandi, Bandung: Mizan, 1987.

Sabiq Sayid, Fiqh Sunnah, Dar al Bayan, Jilid 3, Kwait 1968.

Saifuddin Azwar, Zakat Produktif dalam Perspektif Hukum Islam, Yogyakarta: Pustaka Pelajar 2005.

Shaukani Muhammad bin Ali, Nailul authar sharah muntaqal akhbar, Mesir: Mustofa, al-Babi al-Halabi wa Auladuh, tt.

Shiddieqy M. Hasbi asy, Pedoman zakat, Bulan Bintang, Jakarta, 1953.

Suryabrata Sumadi, Metodologi Penelitian, Cet.XIII; Jakarta: PT RajaGrapindo Persada, 2000.

Syarbiny al Khatib Muhammad, Al Iqna', PT al Ma'arif, Bandung, tt.

Zuhaily Wahbah, Al Fiqh al Islamiy wa Adillatuh, Dar al Fikr, Damskus, Cetakan ke 2, 1984. 
Husnul Yaqin

\section{Sumber Wawancara}

Ketua BAZNAS Provinsi Papua Ir.H.Edi Mirza Nazari, pada tanggal 04 September 2018.

Wakil ketua BAZNAS Provinsi Papua bapak H. Syafi'i, pada tanggal 04 September 2018.

Data di peroleh dari Bendahara BAZNAS Provinsi Papua: Ibu Nalah tanggal 19 September 2018. 